\title{
The effects of climate change on people in the Andes: melting glaciers mean drought, tension and conflict for Peru's mountain people in and around Huascarán National Park
}

\section{Rodney Garrard}

Keywords: societal impacts of glacier change, water supply, climate change mitigation, conservation, livelihoods and development, participatory natural resource management

\section{Abstract}

The effects of climate and glaciers on society have been particularly severe in Peru's Cordillera Blanca (White Mountains) - home of the indigenous Quechua-speaking people. Some even go so far as to say Peruvians have paid a higher price than most for melting glaciers. Yet, despite convincing arguments in call-to-action internet bulletins and scientific articles, little information is available regarding human responses to, or societal impacts of, diminishing glaciers in mountain regions, especially those in developing countries.

\section{Profile}

Protected area

Huascarán National Park

Mountain range

Cordillera Blanca

Country

Peru

\section{Quantifying glacier change}

Every year since 1941, glaciologists have endured weeks at high-elevation glacial lake camps, working in oxygen-deprived air and listening through cold nights to the haunting sounds of grinding glaciers overhead (Carey 2008). Their aim is to continue the work established by Hans Kinzel, one of the pioneers of systematic research in Peru's Cordillera Blanca, which contains 600 glaciers and an ever-growing number of glacial lakes. This is one of the longest running research programmes on glacier-climate dynamics in the tropics. Scientists from across the world now meet regularly to study this vital archive, to share data collected from test sites in other mountain ranges and to mull over the implications of their findings (Vuille et al. 2008). Each year, their frowns of concern deepen.

\section{Implications for society}

Unlike many other consequences of climate change, melting glaciers are highly visible and widely recognized by people around the world. Today, there is overwhelming evidence - both anecdotal and scientific - of global glacier retreat, which is likely to accelerate in coming decades. Every day seems to bring more news of the far-reaching, even catastrophic consequences that diminishing glaciers will produce. Today, on web postings and in many popular articles, people speak of glaciers as if they are an endangered species that deserves protection against extinction (Carey 2010). Meanwhile, millions of people in mountain areas worldwide face potential water shortages as glaciers disappear. A significant proportion of the world's population depends upon water released seasonally from mountain glaciers and snow. The media,

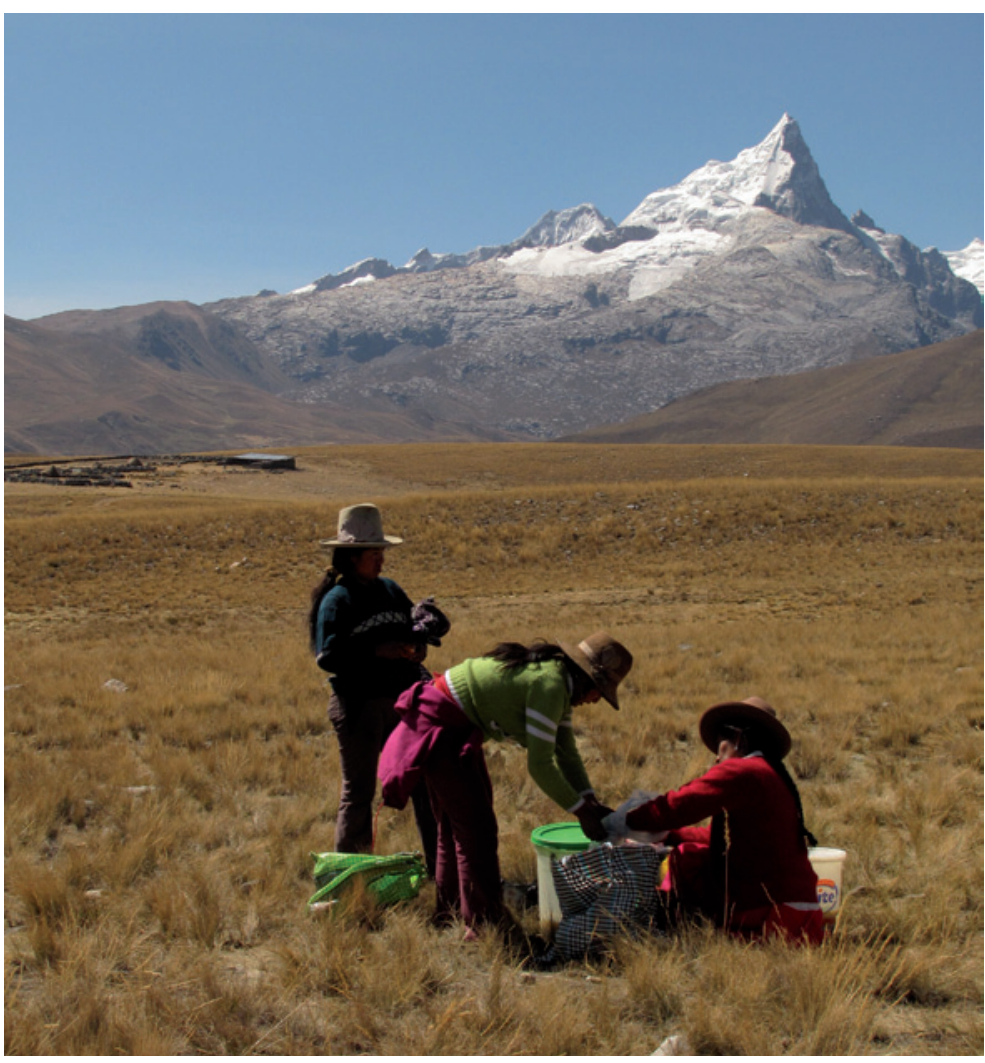

Figure 1 - Soils in the valleys of Cordillera Blanca are very fertile and continue to be farmed by Quechua people as they have been for centuries. (C) Florencia Zapata

in chasing the latest sweltering summer story, no doubt exaggerate cataclysmic scenarios of natural disasters, water shortages, the demise of agriculture and degraded tourist destinations to prey on people's disaster fears - what the BBC has termed climate porn (BBC 2009). But, if only a few of these future scenarios come true, the economic, ecological and social costs to humanity will be enormous. 


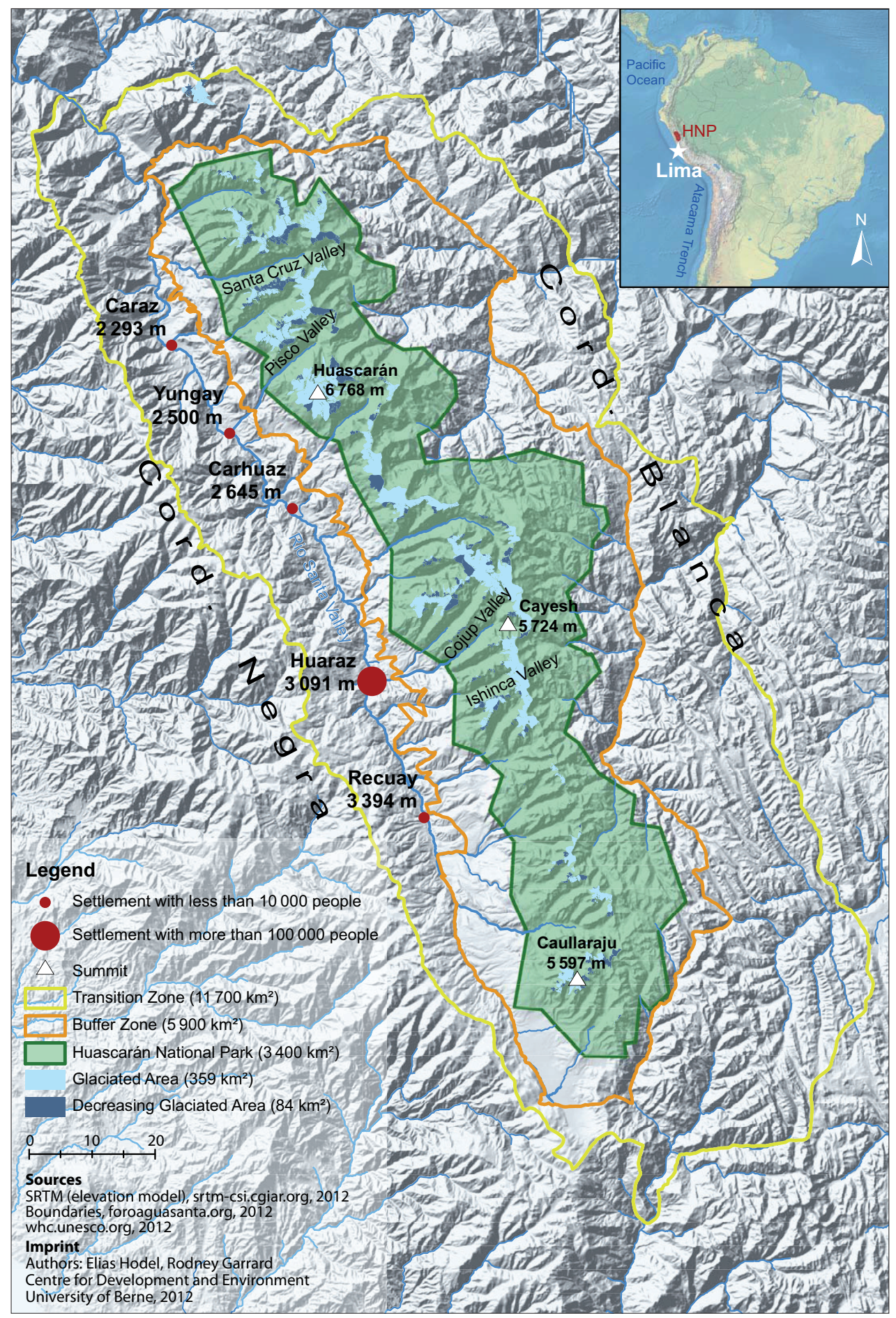

Figure 2 - Map of Huascarán National Park (HNP), highlighting the park \& World Heritage Area boundaries. Design: Elias Hodel \& Rodney Garrard

Hot ice

Despite their seemingly remote locations, glaciers have advanced to the centre of climate change discourse on every continent, not only about the science of climate change but also about issues such as sustainable development, environmental management, watershed protection, regional and global economics, the role of protected natural areas and religion and cultural heritage. While advances have been made in the physical monitoring, and thus in scientific knowl- edge of glaciers worldwide, we know relatively little about how diverse people respond when glaciers retreat a thousand meters, how they grieve when melting ice triggers a catastrophic flood or landslide and what they perceive as the best or perhaps the only acceptable way to protect their water resources. In fact, the actual ways in which people grapple with environmental changes (or don't) often matter more than science. 


\section{Inca pipelines}

Some of the greatest glacial catastrophes of the $20^{\text {th }}$ century have roared down from the Cordillera Blanca. In one incident in 1970, more than 20000 people were killed in a single debris flow that started when a chunk broke off the face of a large retreating glacier, triggered by an earthquake (Kaser \& Osmaston 2002). Such events are etched in the collective memories of the local residents. The mountain range is Peru's highest and most glaciated, running 180 kilometres north to south and parallel to the non-glaciated Cordillera Negra (Black Mountains) to the west. These two ranges do not roll gently into each other across the horizon; rather, they collide into each other and tower dramatically into the sky, falling steeply to create a valley far below where the Santa River flows south to north. This snake-like relentless northward flow has been the region's lifeline for centuries. 70\% of the Cordillera Blanca's meltwater drains into the Santa River, supporting extensive agriculture as well as livestock for around half a million people who inhabit the valleys and upland slopes surrounding this range. They include the inhabitants of the provincial town of Huaraz $(3091 \mathrm{~m}$ - with an estimated population of $\sim 120000$ people), which is the world's largest city in such close proximity to glaciated mountains.

More recently, the Cordillera Blanca has provided these villagers with hydroelectricity as well as hopes of attracting tourists to one of Peru's poorest areas with the creation of Huascarán National Park (NP) in 1975. The NP covers the whole of the Cordillera Blanca above $4000 \mathrm{~m}$ (equivalent to $5900 \mathrm{~km}^{2}$ including the buffer zone). The glaciologists who have pioneered ways to study and drain dangerous glacial lakes for the last seven decades also became the advocates for the creation of Huascarán NP (Carey 2008), designed as much for encouraging tourism as for preserving nature. Today, no other glaciated mountain range in Peru - and there are 19 others, crowned by a total of 2000 glaciers - matches the amount of tourist traffic in the Cordillera Blanca. 50 years ago, nobody but the locals ventured to the local canyons. Today, a shepherd in Huascarán NP is more likely to meet a glaciologist or a tourist than a fellow shepherd.

\section{Local livelihoods}

The mountain people of the Cordillera Blanca "lead vertical livelihoods," says Jeffery Bury, associate professor of environmental studies at the University of California, Santa Cruz (Bury pers. com. 2009). For centuries, they have taken advantage of every ecological niche. They grow crops in valleys, sometimes right to the edge of glaciers, and graze lamas and alpacas on bleak mountain tops. With more than 60 peaks that rise above 5700 meters, including the country's highest summit (Huascarán $6768 \mathrm{~m}$ ), it is easy to understand why the people living in and below Huascarán NP

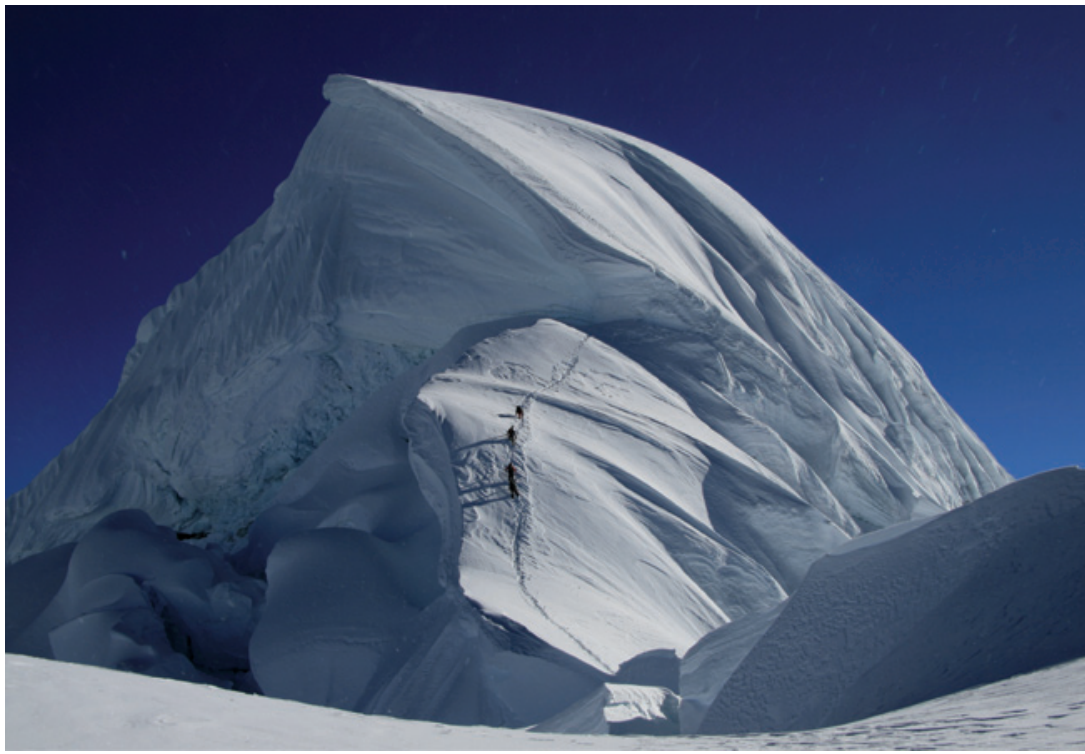

Figure 3-Climbers approaching the summit of Chopicalqui (6345 m). (C) Rodney Garrard

have long worshipped these lofty summits which are the beginnings of countless rivulets that form streams that then flow into rivers far below, providing drinking water and keeping their subalpine pastures alive. The average Peruvian is steeped in a religion that preaches heavy emphasis on the hand of god; the peaks of the Cordillera Blanca are not there to climb but to worship as the abode of powerful deities. The Inca sovereigns revered these mountain spirits, making yearly pilgrimages to the glacierized peaks (Regalado 2005). Such reverence still exists among local residents, although today it no longer takes the form of sacrificing youths and maidens to appease the wrath of the mountain spirits.

But today the way of life for these rural mountain people is changing because of warmer temperatures, in large part due to climate change, that shift crops up mountain sides and affect the seasonal run-off from the glaciers. Water in the dry season comes almost exclusively from glaciers. As Bury outlines, local residents are already being forced to adapt: "They have enough to drink, but it's affecting agriculture, grazing, lake levels and fish in the river. They're concerned." (Bury pers. com. 2009). They also report their distress that the white summits of the nearby peaks are becoming dark - referring to the Cordillera Blanca as sick and demented. Even the Pope recently declared glacier retreat in the Andes a serious humanitarian and religious issue (Carey 2010). In other parts of the world, the sense of identification with glacier-covered peaks, though not phrased in terms of spirits but in terms of social distinction, is still very strong.

\section{World Heritage Area on thin ice}

Lonnie Thomson, professor of geography at the School of Earth Sciences at Ohio State University, has been documenting glacial recession in the Central Andes since the late 1980s. He says that the situation in 


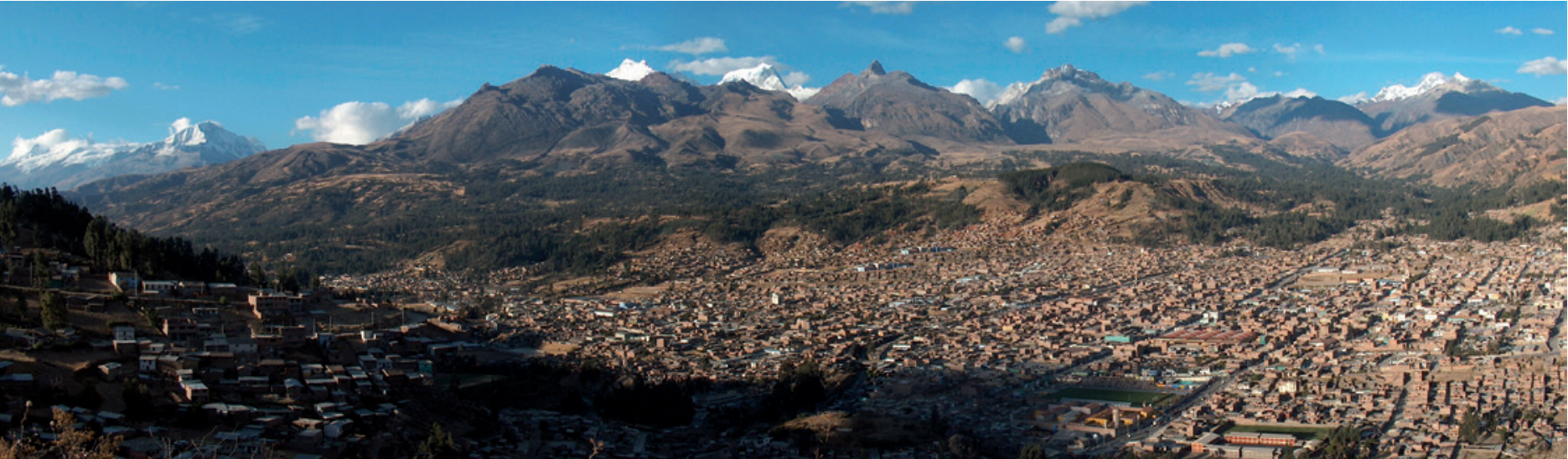

Figure 4 - City of Huaraz (3091 m) ( 120000 population) in Rio Santa Valley, Cordillera Blanca. Background: Huascarán National Park. (C) Esther Hegglin

Huascarán NP today is "very alarming" (Thomson pers. com. 2009). The Cordillera Blanca has lost $27 \%$ of its glacier coverage since $1970\left(187 \mathrm{~km}^{2}\right)$, and $11 \%$ of this loss occurred in the six years between 1997 and 2003. The retreat of these glaciers provides eminently useful information for the current discussion on climate change. However, these trends are real and immediate to the residents living in and around Huascarán NP. "Most of these people have lived beneath these glaciers their entire lives - they can point to where the glacier was when they were children, and now the ice is disappearing", says Jeffery Bury (pers. com. 2009). The residents of Huascarán NP, like so many other rural mountain people around the world, have the unfortunate distinction of being at the forefront of the impacts of climate change, which might be termed a narrative of victimhood - the people directly affected by glacier retreat passively suffer the actions of others. They make a very small direct contribution to the worldwide emissions of greenhouse gases that are the root cause of climate change and are the furthest removed from the decision-making process (Adger et al. 2001).

Melting glaciers are not the only concern for the rural people of this region, says Alton Byers of The Mountain Institute. "These people's livelihoods are being further squeezed by other issues, including the loss of critical vegetative coverage, overgrazing of alpine and subalpine pastures, concentrated tourism, government polices supportive of resource extraction, particularly within the national park, and subsequent external pressures such as new roads, mining and bydropower projects, and this is creating a lot of tension in the surrounding communities" (2009). Yet, Huascarán NP is strictly protected, the equivalent of category II in the International Union for Conservation of Nature (IUCN) definitions of protected areas, and the park was declared a UNESCO Biosphere Reserve in 1977 and a World Natural Heritage Site in 1985.

\section{Participatory protection}

The issues described above by Byers are neither a local Peruvian phenomenon nor restricted to mountain regions in developing countries: they occur in many parts of the world and raise the question of whether more effective protection of mountain regions in general is necessary. However, to achieve effective conservation and sustainable development in protected mountain areas, the social, economic and environmental benefits of any intervention need to be maximized and the costs minimized. These efforts will also need to be based on participatory processes with local residents or they will be doomed to failure. To date, the communities surrounding Huascarán NP have been comparatively neglected in the national development agenda, with no consideration of the growing risks and increased vulnerability to the impacts of climate change. Aritza Monasterio Bilbao, mountain guide and director of Andinista Adventures - a small tourism operator based in Huaraz, says, "Residents surrounding the park think this area [Huascarán NP] is simply an idea from wealthy countries," meaning the park is basically a playground for foreigners. "They resent the status of the park.", says Bilbao, "and are often opposed to the [park's] regulations" (pers. com. 2009). Given that 226000 residents live in the park's buffer zone, this is a concern.

\section{Opposite interests}

In Huaraz, the city that provides most of the tourism infrastructure for Huascarán NP, residents value the park as a means of gaining income from tourists and many want to see the park continue to be developed as parks are in the US, with shopping arcades, ski lifts, cafes and luxury hotels - often referred to as the Yosemite model of protected areas. There is also a group of protectionists who are often further removed from the park's resources all year round. They see the NP's main purpose as conserving biodiversity and natural resources, as well as protecting the park from more mining and hydroelectric projects. Of course, the viewpoints are more diverse than I have outlined here, but my point is that the residents in close vicinity of Huascarán NP have competing desires, some of which are controversial, and many are at odds with 
the park's conservational and sustainable development realities. We must also take into consideration Peru's recent transformation into a neoliberal, mineral-based, export-oriented country and the fact that its political institutions are aligned with this new ideology.

\section{Socio-political instability}

The Cordillera Blanca has long been blessed and cursed with water resources. On the one hand, the massive glaciers and multitude of glacial lakes represent a major resource for clean water as well as tourism and hydroelectric power generation which are the envy of surrounding countries. On the other, climate change is altering the rhythm and amount of available water and causing new natural hazards. But the water crisis in the Cordillera Blanca is not simply a matter of scarcity. Poverty, power and inequality are also at the heart of the problem. As globalization reaches the far corners of the world, the privatization of water in the region has engendered numerous conflicts which will only increase with very powerful mining and exportled agricultural interests as the new elite actors. Unfortunately, the indigenous Quechua-speaking mountain people of the region are cases of double exposure in which local residents are subject to the impacts and events linked to climate change as well as the transformative processes of globalization. At the time I was in Huaraz, there was a regional strike due to local residents contesting water rights. Such untenable attempts to privatize water sparked two months of protests in July 2009 that resulted in injuries to people and damage to infrastructure.

\section{Climate change and forests}

On our current path of climate change thinking, it seems as though park authorities cannot do much about the region's tropical glaciers - any direct localized mitigation effort is only going to be short-term. You see this internationally; ski resorts from Switzerland to British Columbia are increasingly relying on artificial snow-making and even cover glaciers with synthetic white tarpaulin to prevent the melting of valuable ski terrain (BBC 2007). Tellingly, it was only three generations ago in Europe when the same populations used to send their priests up to the glaciers to pray to God to stop them encroaching further down the valley. But what park authorities in Huascarán NP can do is buffer the impacts of climate change by restoring and protecting the forests, grassland and alpine ecosystems in the upper reaches of the park. For example, the park's remaining quenual forests (a Polylepis species) cover a mere remnant of their former range, most likely because of accelerated logging since colonial times, says Alton Byers (Byers pers. com. 2009). The restoration of these quenual forests would result in cooler environments, better infiltration and storage of water, higher biodiversity and more niches for vulnerable

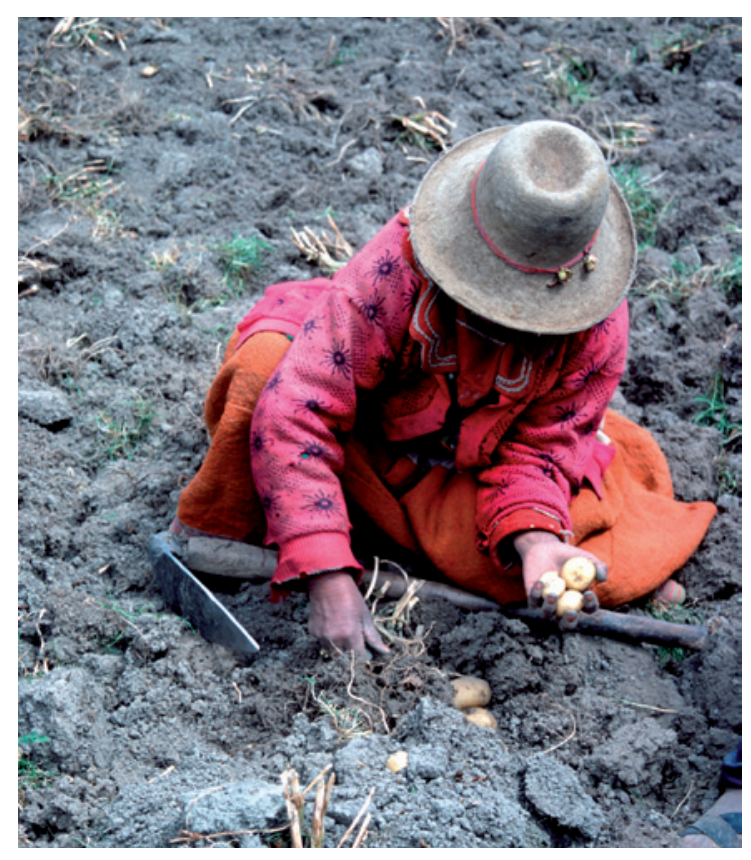

Figure 5-A Quechua woman tending her potato crops, Cordillera Blanca. Quechua farmers have used these same agricultural methods for centuries. (C) Florencia Zapata

plants and animals. For much of the Santa River Valley and areas surrounding Huascarán NP, the dominant sector of the economy is agriculture. This production is largely dependent on the availability of irrigation water. Reduced water availability, coupled with the increase in temperature in most parts of the Cordillera Blanca, will require massive adaptation in upstream as well as downstream locations. I do not want to create the romantic notion that the Incas were ecologically sound, but a quick survey of Inca geography reveals carefully cultivated stone aqueducts constructed over 500 years ago that still carry water - undeniable evidence of sensible planning of long ago.

\section{So, what is our role as visitors?}

Unless we understand the socio-economic environment across which we are traipsing with our highaltitude equipment and cameras, and show some real tact, we threaten the dignity of the poor communities that we pass through. With care and preparation, we can start to understand the causes of poverty and leave more behind than rubbish and a beggar mentality. We can minimize our impacts and maximize the benefits of our visit by supporting community-based conservation and livelihood projects. For example, the Alpine Conservation Partnership's (ACP) role in Huascarán NP has measurably improved the alpine grassland in the Ishinca and Pisco Valleys. The ACP is a locally based joint venture between the Mountain Institute and the American Alpine Club. Such community-based projects are key elements, not only in conservation gains for the region, but they also play a vital role in developing adaptive capacity. Lastly, we must promote thinking and get involved in how par- 
ticipatory conservation that is in touch with local concerns and realities can be an integral part of protected mountain areas planning in the near future - this is critical for successfully dealing with the effects of climate change.

\section{Acknowledgment}

In July 2009, I attended the conference: Adapting to a World without Glaciers: realities, challenges and actions in Lima / Huaraz. The conference gathered leading scientists from glaciology, geography, resource management and related fields to discuss the latest research on mountain glacier meltings and the consequent effects on downstream regions. Comments in this article are taken from discussions at this workshop. I thank Lonnie G. Thompson, Alton Byers, Jeffery Bury and Aritza Monasterio Bilbao for their comments. For me, the time spent in Huascarán NP during the conference revealed a glaring gap between the existence of park regulations and the reality of implementation on the ground, and alerted me to the need for adaptation policies for those most vulnerable. Thankfully, this gap in knowledge is starting to get the attention it deserves, for unless we overcome that gap, policy aimed at minimizing human costs cannot be formulated.

\section{References}

Adgar, W.N., T.A. Benjaminsen, K. Brown \& H. Svarstad 2001. Advancing political ecology of global environmental discourses. Development and Change 32: 681-715.

BBC 2007. Cloak protects glacier from sun. Available at: http://news.bbc.co.uk/2/hi/europe/4533945.stm (accessed: 17/06/07)

BBC 2009. Media attacked for climate porn. Available at: http://news.bbc.co.uk/2/hi/science/nature/5236482.stm (accessed: 01/08/09)

Borsdorf, A. \& C. Stadel 2001. Peru World heritage area melts im Profil. Landeskundliche Beobachtungen auf einer geographischen Exkursion 2000. inngeo 10 - Innsbrucker Materialien zur Geographie 10. Innsbruck.

Byers, A.C. 2009. A comparative study of tourism impacts on alpine ecosystems in the Sagarmatha (Mt. Everest) National Park, Nepal and the Huascarán $\mathrm{Na}$ tional Park, Peru. In: Hill, J. \& T. Gale (eds.), Ecotourism and Environmental Sustainability. London.

Carey, M. 2007. The History of Ice: How Glaciers Became an Endangered Species. Environmental History 12 (3): 497-527.

Carey, M. 2008. The Politics of Place: Inhabiting and defending glacier hazards in Peru's Cordillaera Blanca, In: von Benjamin, S., E. Orlove, B. Wiegandt \& H. Luckman (eds.), Darkening Peaks: Glacial retreat, science and society.

Carey, M. 2010. In the Shadow of Melting Glaciers: Climate Change and Andean Society.
Galvin M. \& T. Haller (eds.) 2008. People, Protected Areas and Global Change: Participatory Conservation in Latin America, Africa, Asia and Europe. Perspectives of the Swiss National Centre of Competence in Research (NCCR) North-South.

Jungmeier, M., I. Paul-Horn, D. Zollner, F. Borsdorf, K. Grasenick, S. Lange \& B. Reutz-Hornsteiner 2011. Biosphere reserves as a long-term intervention in a region - strategies, processes, topics and principles of different participative planning and management regimes of biosphere reserves. eco.mont 3 (1).

Kaser, G. \& H. Osmaston (eds.) 2002. Tropical Glaciers. Cambridge.

Lange, S. 2011. Biosphere reserves in the mountains of the world and their standing after 40 years of UNESCO's MAB Programme. eco.mont 3 (1).

Regalado, A. 2005. The Ukukus Wonder Why a Sacred Glacier Melts in Peru's Andes; It could portend world's end, so mountain worshippers are stewarding the Ice. Wall Street Journal. Eastern Edition. June 17, A.1.

Vuille, M., G. Kaser \& I. Juen 2008. Glacier mass balance variability in the Cordillera Blanca, Peru and its relationship with climate and the large-scale circulation. Global and Planetary Change 62 (1-2): 14-28.

\section{Author}

\section{Rodney Garrard}

is a Ph.D. Candidate at the Centre for Development and Environment (CDE), University of Bern, Switzerland. His dissertation is exploring landscape dynamics in the Everest region, Nepal: www.garrard.co.nz

Rodney is also a member of the UIAA Mountain Protection Commission; IUCN WCPA Tourism and Protected Areas Group and IUCN's World Commission on Protected Areas (WCPA). email: rodney.garrard@cde.unibe.ch 